\title{
Grammar Errors Made by ESL Tertiary Students in Writing
}

\author{
Charanjit Kaur Swaran Singh ${ }^{1}$, Amreet Kaur Jageer Singh ${ }^{2}$, Nur Qistina Abd Razak ${ }^{2}$ \& Thilaga Ravinthar ${ }^{2}$ \\ ${ }^{1}$ Faculty of Languages and Communication, Sultan Idris Education University, Perak, Malaysia \\ ${ }^{2}$ Centre for Languages and General Studies, Sultan Idris Education University, Perak, Malaysia \\ Correspondence: Charanjit Kaur Swaran Singh, Faculty of Languages and Communication, Sultan Idris \\ Education University, Perak, Malaysia. E-mail: charanjit@fbk.upsi.edu.my
}

Received: February 6, 2017 Accepted: April 1, 2017 Online Published: April 4, 2017

doi: 10.5539/elt.v10n5p16 URL: http://doi.org/10.5539/elt.v10n5p16

\begin{abstract}
The educational context in Malaysia demands students to be equipped with sound grammar so that they can produce good essays in the examination. However, despite having learnt English in primary and secondary schools, students in the higher learning institutions tend to make some grammatical errors in their writing. This study presents the grammatical errors made by tertiary students in their writing. The participants were a group of Diploma students who sat for a university entrance exam. One hundred and forty-four written essays of the students were collected and analysed using content analysis. Findings revealed that subject-verb agreement and tenses were the most common type of errors. Students over-generalised and perceived that the tenses could be used interchangeably. Another common error found was in the students' construction of complex sentence. In such constructions, they failed to include essential and nonessential clauses. If teachers do not teach strategies to assist students in comprehending the concept of Subject-Verb Agreement (SVA), tenses, essential and nonessential clauses, these students will continue to make such errors in their tertiary education. The findings may have useful implications for English language teachers as understanding students' learning difficulties and providing appropriate grammar instruction is the key to effective teaching for ESL teachers.
\end{abstract}

Keywords: error analysis, grammatical errors, essays, ESL students

\section{Introduction}

Grammar is viewed as the most essential aspect of language learning for second language learners. In Malaysia, it is crucial for learners to master knowledge of grammar as English had been used extensively as the medium of instruction at secondary schools for decades before the Malay language replaced it in 1981. Previous studies strongly recommend that the most beneficial approach of facilitating learners' command of grammar in writing is to employ students' writing as the starting point for discussing grammatical concepts. Researchers agree that it is more effective to teach punctuation, sentence variety, and usage in the context of writing than to approach the topic by teaching isolated skills (Calkins, 1980; DiStefano \& Killion, 1984; Harris, 1962). When students revise and edit their writing, teachers can facilitate grammar instruction that directs students in their efforts to recognize and correct errors in usage (Chin, 2000). As suggested by Chin (2000), a teacher who sees that many students are writing sentences containing misplaced modifiers can present a mini lesson on this concept, using examples from student writing. The teacher can instruct the students to exchange their own drafts with their peers for editing purpose. Integrating grammar instruction into the revising and editing process assists students in making immediate applications, thus allowing them to see the relevance of grammar to their own writing (Chin, 2000).

Writing is viewed as a complex and challenging activity for many students; teachers should focus on the grammatical concepts essential for clear communication of meaning (Chin, 2000). Research conducted during the early 1960s shows that grammar instruction that is separate from writing instruction does not improve students' writing competence (Braddock et al., 1963; Hillocks, 1986, cited in Chin, 2000). In addition, research reveals that the transfer of formal grammar instruction to writing is not applicable to larger elements of composition. Through detailed studies of student writing, Shaughnessy (1977) concludes that the best grammar instruction is that which gives the greatest return for the least investment of time. Shaughnessy (1977) advocates four important grammatical concepts (as cited in Chin, 2000): the sentence, inflection, tense, and agreement. She recommends that teachers encourage students to examine grammatical errors in their own writing. She also 
cautions teachers not to focus on grammatical terminology to the detriment of students' ability to understand and apply the concepts.

Evidence of the growing need to master essay writing has become increasingly important in the Malaysian ESL context. The students need to master how to transfer the knowledge of grammatical concepts to their written work, so that they will not commit many grammatical errors in writing. In Malaysia, students who are able to comprehend the knowledge of grammar will be at an advantage because English is a compulsory subject in the curriculum, and the educational context in Malaysia emphasises writing as compared to other skills. There is therefore a need for the students to have sound knowledge of grammar. Despite the exposure to English language, both primary and secondary schools students still struggle in writing well. Students' inability to write well is believed to be due to the influence of their mother tongue and also insufficient knowledge of grammatical rules and concepts. In report writing, students need to know the appropriate use of tenses. Regardless of the many exercises done in school, these students are still unsure about the choice of tenses appropriate for report writing. There are a few general rules of thumb for report writing. This study highlighted the common grammatical errors in writing by Diploma in English students of schools from different districts in Malaysia. The objective of the study is to identify the grammatical errors made by the ESL students in writing.

\subsection{Objectives of the Study}

This study is carried out based on the following objectives:

1). To identify the grammatical errors committed by ESL students in writing.

2). To investigate the various forms of errors in the use of tenses committed by ESL students in writing.

\subsection{Statement of the Problem}

The National Education Blueprint (2013-2025) aspires at raising standards and quality of Malaysian education including developing cognitive skills. In Malaysia, researchers have pointed out the students' unsatisfactory writing skills after years of taking English lessons at school (Pandian, 2006; Ramaiah, 1997). The 2005 School Certificate Examination Report on English Language 2 revealed that the majority of candidates were very weak and have yet to master writing skills in English (School Certificate Attainment Report, 2005). Literature revealed that some students having learnt English for eleven years could not produce even a short paragraph of intelligible writing (Khairiah, 1970). Studies have examined the problems faced by teachers in teaching writing skills (Palpanadan, Abdul Rahim Salam \& Fauziah Ismail, 2014). Writing skill is considered as the most difficult task for students because they are not proficient in the language and do not have good mastery of vocabulary and grammar. They have limited exposure to the language and seldom communicate using the language in daily life.

Writing is a genuine challenge faced by teachers in ESL classrooms (Zerin, 2007). The skill needs to be developed from an early age. Teachers need to introduce interesting teaching strategies and teaching aids to arouse student interest in learning English. Every effort that teachers make can mark a significant milestone in the process of learning English and benefit the students. This view has also been expressed by Nunan (1999) who states that the most difficult task in writing is to produce a coherent and fluent extended piece of writing. This is particularly so when it comes to writing in a language which is different from one's first language. Hence, many learners of English as a second language, especially at secondary school level, perform poorly in the language during examinations. For example, the results of the SPM (Sijil Pelajaran Malaysia) examination English Paper for 2014 showed that $77.3 \%$ of the students passed compared to 80\% in 2013 (The Star Online, 2014). Part of the examination paper is based on writing. Students often display weaknesses in their written work; these weaknesses are seen in the structures they produce and also in the ideas expressed (Mohtar et al., 2017).

\subsection{Research Question}

This study is conducted in reference to the following research question:

What are the grammatical errors committed by ESL students in writing?

\subsection{Significance of the Study}

This study attempts to provide an overview of most common grammatical errors made by ESL students in written form. ESL students are taught grammar much more than any other language aspects, especially in formal classroom context. However, there is the need for students to be informed on the common errors they commit. In addition, it is worthwhile for teachers to know the causes of the same errors committed by students so that ways to reduce them could be figured out. This study hopes to give a new insight to English teachers that teaching writing skill is not difficult as long as they employ the correct use of grammar useful to the students. Teacher should be critical and creative in teaching grammar that helps to improve students' writing skill. This would help 
to enrich the writing topic that students could relate in their experience. The research recommends teachers should prioritize and provide instruction on the grammatical elements that most affect their students' ability to write effectively. Teachers should also be sensitive to individual students' readiness to learn and apply grammatical concepts. For syllabus and curriculum designers, this study might be a useful platform for additional reference since it is hoped to be able to focus on the grammatical aspects which need to be highlighted on the students learning in school. Also, educational book publishers who might want to modify their publications by publishing grammar books on several grammatical aspects based on students' needs. This is due to the finding which shows that different students face different difficulties and problems in diverse grammatical aspects. Workbooks or references published with standardised quality could also be the supplementary resources for students to work out on their respective areas of grammar problems.

\section{Literature Review}

\subsection{Error Analysis}

Error analysis is one of the most influential theories of second language acquisition. It is concerned with the analysis of the errors committed by L2 learners by comparing the learners' acquired norms with the target language norms and explaining the identified errors (James, 1988). For Crystal (1999, p. 108) error analysis in language teaching and learning is the study of the unacceptable forms produced by someone learning a language, especially a foreign language. According to James (2001, p. 62), EA refers to "the study of linguistic ignorance, the investigation of what people do not know and how they attempt to cope with their ignorance".

\subsection{Error Correction Techniques in Writing}

Error Analysis (EA) is an approach of linguistic study that focuses on the errors learners make and it assists educators in understanding the language learning process. Since various errors are seen as a means to an end, some researchers tend to discover the appropriate corrective techniques that can aid effective learning and teaching of English. This is because through writing one can evaluate the language competency, capability to recall and capability to think (Javed et al., 2013). Saadiyah and Subramaniam (2009) used Error Analysis (EA) to examine errors in a corpus of 72 essays written by 72 participants. Corder who is the "father" of EA, explained EA in his article titled "The significance of learner errors" (1967). Errors used to be "flaws" that needed to be eradicated in writing. However, Corder (1967, pp. 19-27) presents a completely different point of view by saying those errors are "important in and of themselves". In his opinion, systematic error analysis can enable teachers to determine the kind of reinforcement needed in teaching. In this regard, this study has shed light on how students internalise the rules of the target language, which is English. In addition, EA is found to be useful to teachers as it provides information on common trouble spots in language learning to guide preparation of effective teaching materials.

Furthermore, Wee et al. (2009) use overt teaching to reduce subject-verb agreement (SVA) errors of Malaysia EAP learners. The explanation of the rules of a new structure either through the deductive (direct) approach or through the inductive (discovery) approach has greatly benefitted the subjects. Comparison of the data from the subjects' pre-test and post-test shows a drastic decrease in the frequency of errors in the targeted SVA error forms after overt teaching. Besides that, Ruziah (2006) has enhanced the correct use of prepositions through error identification drill exercises among the 17 KPLI (M) students. Even though both findings showed positive outcomes, these outcomes are only applicable for certain aspects that are on SVA and prepositions in writing. Further research is needed to explore better ways to reduce the grammatical and mechanical types of errors in L2 student writing.

Krashen (1984) claims that language acquisition occurs naturally and the ability to write is influenced by the exposure to natural materials and not through the learning of grammar in isolation. This has raised concern regarding the suitability of error correction in reducing the errors made by students. According to Corpuz (2011), the approach is said to be lacking in validity, effectiveness is difficult to be measured and it may be harmful in the context of learning. However, according to his study the error correction technique benefits teachers in creating awareness among learners, in instilling independent reading habits among students besides aiding revision.

Reflecting on these techniques, we feel that error analysis can help teachers to detect and analyse students' errors which aims to provide room for improvement. Indeed, this move will shed light on the difficulties faced by the students besides revealing the underlying reasons for these errors. Teachers can also gain benefits in designing or planning strategies and measures to help students overcome their problems and improve their language performance (Norasiah Muhari \& Wan Fara Adlina Wan Mansor, 2008). Systematic and planned teaching of a particular grammatical or mechanical feature in language input can be carried out smoothly instead of cramming 
everything into the daily lessons. Myles (2002) also mentions that feedback is the most significant part of writing and that improvement is impossible without it. Indirectly, these will be able to inculcate awareness among the students of the common types of errors to avoid (Naeini, 2008).

For ESL students who are starting to learn a new language, it is essential that they learn the basic grammar rules of the target language first. In the Malaysian educational context, students are expected to write grammatically correct sentences as much focus is given to written examinations. Grammar is the foundation of language learning for second language students (Foppoli, 2012). Corder (1978) maintains that interlanguage can be seen as a restructuring or a recreating continuum and, therefore plays a role in second language acquisition. Second language students are unaware of their errors because they have insufficient knowledge of the system of the language that they are learning. This is related to Krashen's Monitor Model (1982) emphasising the study of the rule of the target language as a process of learning. This is also supported by Carter (1997) who suggested that "knowing more about how grammar works is to understand more about how grammar is used and misused". Knowledge of grammar is not just about mastering by expressing the rules by memorizing but the students have to be aware of the errors or mistakes they make as well. Brown (1980) asserts that the process of human learning is closely related to the frequency of making errors and this led to error analysis as linguists have realised how errors can provide clues to problems in L2 learning.

In the Malaysian context, many studies have been conducted on common grammatical errors in the writing of ESL students. Ghabool, Edwina, and Kashef (2012) revealed that Malaysian ESL students have problems in writing, especially in language use (grammar) and punctuation. Students still need some constant monitoring and explanation from the teachers specifically in developing a good piece of writing. Thus, when the teachers spend some time reading students' essays and providing feedback, it would help the students to recognize the common errors they made. Upon receiving the feedback, students should work immediately to improve their essays. Similar findings were reported by Musa, Lie, and Azman (2012) who found that students were too dependent on their mother tongue when it comes to writing. The interference of L1 was viewed as an obstacle to further motivate students to write and achieve good grades in essay writing. The researchers investigated all types of errors using the error analyses and contrastive analyses among 120 students in three parts of Malaysia. Their findings revealed the difficulty in using the correct form of English grammar was the main problem in Malaysian students' essay writing. Three recurrent grammatical errors were reported including the misuse of articles, to be verb, and subject-verb agreement. They also concluded that the reason behind students' grammatical errors was the first language's interference which is Malay Language in the context of the study. Myles (2002) says that students who have ability to write in their mother tongue are able to transfer the skills in writing for L2 and having incompetence in their mother tongue may serve as a hindrance in writing in L2.

Narinasamy, Mukundan, and Nimehchisalem (2013) in their study reported that Malaysian students had minor problems in using modal verbs grammatically in argumentative writing. Their findings revealed that Malaysian students preferred to use a lot of modals in their writings. However, the use of these modals was limited to a few words only. It was concluded that despite the inaccuracies in terms of meanings, most students were able to use syntactically accurate modals in their sentences. In addition, Darus and Subramaniam (2009), using Corder's (1967) model on error analysis, examined errors in a corpus of 72 essays written by 72 Form Four Malay students. They found that most of the students committed six common errors: singular/plural form, verb tense, word choice, preposition, subject-verb agreement and word order. Wee (2009) and Nor Hashimah et al. (2008) also reported that errors that students in respective studies committed were basically grammatical. Based on the various errors committed by students in previous studies, the researchers decided to focus on analysing frequent grammatical errors in essay writing that disrupt the writing flow.

\subsection{Misformation}

Wee et al. (2010) claim that misformation occurs when wrong forms are used in the subject-verb agreement process. For instance "students is..." and usage of the tense is wrongly reflected in the writing. In this study, researchers focused on the general misformation that the students committed. Based on Zheng and Park (2013), misformation can be categorised into noun misformation, verb misformation and even preposition misformation. As for this study, we are not attempting to classify the errors but we intend to analyse the common misformation that appears to assist teachers in planning for student learning and assessment. Zheng and Park (2013) in their study focused on Korean and Chinese students where the misformation was due to the errors not being highlighted and explained to the students. Thus, this explains the significance of identifying errors in writing to improve student writing. According to them, students are prone to fossilization if the error is not corrected immediately as fossilization interrupts the fluency and accuracy of learning a second language. Therefore, it leads to the notion of the research, which is to identify the grammatical errors committed by students in writing. 


\subsection{Theoretical Basis}

The theoretical basis for this research is provided by two renowned researchers in cognitive psychology mainly Bruner (1975) and Vygotsky (1978), and one researcher in second language acquisition, Krashen (1981). Vygotsky introduced the concept of zone of proximal development which is a gap between the learner's current ability and the learner's potential level of development which is achieved under adult guidance. Carl Rogers's (1967) facilitation theory is based on the humanistic approach which emphasises student-centred teaching. According to Rogers (1967), the facilitation is provided by the teacher who does it through his or her attitude in his or her personal relationship with the students. Krashen's theory states that comprehensible input is crucial in allowing language acquisition to occur. This input may be slightly higher $(i+1)$ than the learner's current proficiency level (i). Hence, language input that is comprehensible will enable the second language learner to learn the language. Any input that is higher than $\mathrm{i}+1$ will be difficult for the learner to acquire. In addition, Krashen claims that language cannot be acquired if the affective filter is raised. A learner who is emotionally disturbed will not be able to learn any new language even with comprehensible input. His approach is on the importance of having low anxiety in the process of learning and provides significant input which caters to learner needs. This study will also incorporate the structural approach which focuses on repetition of structures but in a meaningful way.

According to social-cognitive theories the social contexts for writing operate together with the cognitive efforts of the writer. Second language writing involves the cognitively demanding task of generating meaningful text in a second language. Hence second language students need more teacher involvement and guidance. Teachers need to understand the social and cognitive factors involved in the second language acquisition process and errors in writing as these factors have an important effect on L2 writing development (Myles, 2002). In view of such needs, it is intended in this study to provide the students' guidance in the form of grammar to enable them to write compositions in English and to explore the extent to which it will help the learners develop their language proficiency as they acquire the writing skill.

\section{Methodology}

This part addresses the research design, procedure, participants, instruments, and data collection procedure. A qualitative research design was chosen for this study because the methodology best allowed the researchers to collect data to answer the research question.

A qualitative approach was employed throughout the whole study. Case study allows for an in-depth investigation which highlights a detailed insight of the particular phenomenon of a study and diverse characteristics of the concerned population (Kaufman \& Kaufman, 2004). A case study research design allowed in-depth analysis of the classroom context in which intervention takes place and facilitated enhancement of the description of the intervention itself (Ganapathy \& Kaur, 2013). This is a case study which looked into grammar errors made by the ESL students. The case involved a group of tertiary ESL students who submitted their essays for entrance examination. The essays collected were the outcomes of the case which referred to the common grammatical errors made by the ESL students. The number of errors made was also recorded.

\subsection{Participants}

The sample was selected based on convenience sampling as they were accessible to the researchers. The participants in this study were one hundred and forty-four Diploma students from various schools in Malaysia. The students were mostly Malays. Their age range was between 18 to 20 years. Their English language proficiency was at a moderate level. The students were taught report writing and grammar rules in their secondary schools.

\subsection{Data Collection}

Data for the research were obtained using essays of the respective students.

\subsubsection{Tests}

Altogether, there was one essay task which students had to complete. They were given forty minutes to write the essay. The essay was rated by a lecturer who had taught English language for more than 20 years in the University. This lecturer was not attached to any of the schools the students came from and did not know any of them. The marking criteria for the writing included title, introduction, conclusion, grammar, content and elaboration, language, mechanics of writing, vocabulary, requirement of tasks, and interest of reader arousal. The total score was 50 . 
The students took the entrance exam to enable them to secure a place in the University. The students were given forty minutes to write the report of 250 words. The data were collected in written form based on the students' writing in the report form. Numerical data were also collected when it came to counting the number of errors (to be converted into percentage and mean score). All the hundred and forty-four written reports were collected and marked. Specific grammatical errors marked were extracted to be grouped into several categories including parts of speech and tenses, which emerged based on the written reports. Content analysis was used to analyse the students' written report. In content analysis, the researchers classified the key ideas in a written communication, such as a report, article, or film (Crowley \& Delfico, 1996). Researchers can do content analysis of video, film, and other forms of recorded information, but in this study, we focused on analysing words based on the students' report writing. The analysis stage included reading the written report 2-3 times, counting the number of errors in the respective categories before making a comparison based on frequencies and mean score values of the error types.

\subsection{Data Analysis}

Data obtained from the essays were recorded in descriptive terms using the table form checklist. The analysis of grammatical errors was divided in terms of type of error and its frequency. Descriptive statistical analysis was carried out to show the following: percentage of the type of error made; the mean score of the error; and its frequency.

\section{Findings}

Table 1 shows the analysis of grammatical errors based on type of error, number of errors, percentage and mean score values of errors committed by the students.

Table 1. Grammatical errors made by ESL students in writing

\begin{tabular}{lllll}
\hline Item & Type of Error & Frequency & Percentage (\%) & Mean \\
\hline 1. & Subject - Verb Agreement (SVA) & 258 & 34.7 & 1.79 \\
2. & Verb Tense & 226 & 30.4 & 1.57 \\
3. & Noun & 141 & 19.0 & 0.98 \\
4. & Preposition & 44 & 5.9 & 0.31 \\
5. & Adjective & 34 & 4.5 & 0.24 \\
6. & Article & 19 & 2.5 & 0.13 \\
7. & Pronoun & 16 & 2.2 & 0.11 \\
8. & Adverb & 4 & 0.5 & 0.03 \\
9. & Conjunction & 2 & 0.3 & 0.01 \\
& Total & $\mathbf{7 4 4}$ & $\mathbf{1 0 0 . 0}$ & \\
\hline
\end{tabular}

The table shows nine types of grammatical errors identified based on the students' written reports, which include subject-verb agreement, verb tense, noun, preposition, adjective, article, pronoun, adverbs and conjunction. One hundred and forty-four samples of written reports by Diploma students were collected and analysed. The findings revealed a total of 744 errors. The five most common errors that the students made were in subject-verb agreement $($ mean $=1.79)$, verb tense $(1.57)$, followed by noun $(0.98)$, preposition $(0.31)$, and adjective $(0.24)$. The next noticeable errors were article $(0.13)$ and pronoun $(0.11)$. Other errors amounting to less than 0.1 were adverb (0.03) and conjunction (0.01).

\subsection{Subject-Verb Agreement}

Among all indicated grammatical errors, errors in Subject-Verb Agreement are the most common or prevailing errors of the students in their English writing. It was observed from their written work that students made such errors due to their inability to include the suitable Subject-Verb Agreement, suggesting the students' dilemma in forming the sentences correctly. The majority of the students faced problems in agreement as they could not make the subjects and verbs agree because the verbs do follow their subjects closely and the number of the subject was unclear.

They wrongly matched singular subject with plural verb and vice versa. One participant uses 'are' instead as 
shown in sentence no. 1 . In sentence no. 2 , the correct word should be 'helps'. In sentence no. 3 , 'ensures' should be used rather than 'ensure'. The word 'determines' should be used rather than 'determine' in sentence no. 4.

1) Furthermore, Internet are (is) also used as a social hub such as Facebook, Twitter and sending email to each other.

2) Internet help (helps) us to connect with our family member or beloved ones who are at the foreign country.

3) Asia Prime Minister also ensure (ensures) his people well-known in internet for further education and to increase the economic level.

4) The social lifestyle of the population also determine (determines) the penetration of internet in a country.

In addition, $34.7 \%$ of the students committed errors when a phrase was inserted between the subject and verb, creating an agreement problem, or when the subject a pronoun, the number of which is hard to determine. For example:

1) They also offers (offer) many university (for international students)...

2) These facts shows (show) us the importance and the impact created by the Internet in our daily life.

3) In this new era where technologies were introduced to all people around the world, they seems (seem) to spend most of their time on internet.

In sentence no. 1, the correct word should be 'offer'. In sentence 2 and 3, the correct words should be 'show' and 'seem' respectively. These forms of errors are attributed to students' poor knowledge of the fact that a singular subject takes singular verb and plural subject takes plural verb.

\subsection{Verb Tense}

Students presented major errors in this aspect as they were required to write a report based on stimuli. It is well understood that students with adequate understanding of grammar rules in writing will use the correct tenses to explain facts and other details of the stimuli. For instance, the introduction and conclusion paragraph should reflect the usage of past tense as the essay is reporting about an event that has taken place. However, it is revealed based on this study that students failed to change the verbs into past tense form. The following sentences show more the errors made by students in their writing which was selected randomly.

The country that has internet (was) different in terms of the technology use. Most of them does not have access to

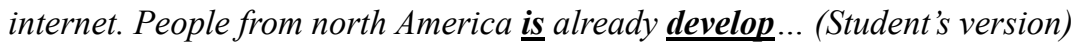

The country with internet is different in terms of the technology usage. Most of them do not have access to internet. People from North America already developed... (Correct Version)

Referring to the excerpt given, words are the verbs which the student did not change using the correct grammatical form. The student should have written as shown in the second example. However, they faced difficulty in selecting the appropriate verbs to be used in writing. For example, the student wrote 'The country that has internet' should be rewritten as 'The country with internet'.

There are two types of Tenses which have not been correctly used and applied in the student's writing: For example:

1) I am wondering how the student in that country were busy to open book.

2) The country have to be exposes children to the internet.

3) That most people that has using.

Three sentences in the preceding excerpts contain errors in application of two types of tenses. Sentence (1) shows the error represented by the phrase 'were busy'. For this example, the student should have applied the rule of Present Perfect Tense which takes the form of verb "to have + a past participle" which should make up the correct phrase of 'has opened'. Putting sentence (1) into the context of report writing, the student wrote the phrase as describing that the students were too busy to open books.

Sentence (2) shows the same repeated error as in sentence (1). Instead of using 'have to be exposes', the learned should have written 'has exposed'. It clearly shows that the student is confused in choosing the correct Verb Form to write and also reflect his/her insufficient grammar mastery.

For Sentence (3), the error is shown by the bold and underlined phrase and is categorized under the use of Present Continuous Tense. This type of tense is used for actions happening at the present time. It takes the form 
of verb to be + (verb+ing), resulting in the correct form of the phrase 'are using' which is supposed to be used in Sentence (3).

Categorization of errors in the use of tenses revealed that the students were not consistent in constructing their sentences. Since the topic of the writing task required the students to write a summary, it was understood that students had to use or write using the active or passive voice. Therefore, students can exchange papers and search for verbs that often signal the passive voice, such as was and been. When students are able to identify these verbs, they read the sentence aloud to their partners and discuss whether the voice is passive and, if so, whether an active voice verb might support the sentence (Chin, 2000). The student can then choose which voice is most effective and suitable for the writing purpose and audience.

1) As for me, the internet penetration showed me that Europe has using the internet...

2) Internet ...is getting higher because the technology was getting modern day by day.

\subsubsection{Verb to Have}

ESL students had difficulty deciding and distinguishing the use of the Verb to Have in a particular context. In some cases the students overcorrected themselves by using the Verbs to Have in a redundant way; they also omitted them to simplify their tasks or replaced them with each other. This showed that the students still had difficulty in understanding the concepts of verbs to have as shown in the examples below:

1) Population like Asia, Middel East and Latin America has average....

2) ...some population in one contries has internet and some doesn't...

3) The north America have the highest percentage of population...

4) While north Africa have less percentage...

5) ...we can conclude that the largest country that have fast growing...

6) ...every countries has access...

7) ...population of people that has internet...

8) ...internet have been...

9) ...different country have different...

10) ...in carribean, they has $30 \%$ of population...

\subsubsection{Auxiliary Verbs}

The following examples revealed how the student had constructed the use of the auxiliary verbs in a wrong manner. There are four errors which showed the inappropriate use of the auxiliary verbs in the examples. In sentence (1) instead of writing 'The person who are...' the student should have written 'The person who is...' In sentence (2), the student should have written 'Their internet usage is'.., In sentence (3), it should be written as 'Based on the graph, there is..' and in Sentence (4), 'The technology in their country is..'. The student should understand that when using the auxiliary verbs in the report writing, there are no actions shown in the examples given. These words talk about the action or the state of any noun or subject. This means that verbs show what the subject is doing or what is the state or situation of the subject.

1) The person who are in Caribbean access internet every day.

2) Their internet usage are more better...

3) Based on the graph, there are a huge different of percentage

4) The technology in their country are more develop than in Asia...

\subsection{Noun}

Some of the students demonstrated confusion in using nouns. The main problem of the students was that they could not differentiate between countable and uncountable nouns. Also, a few of the students were found not knowing that the plural form using the suffix ' $\mathrm{s}$ ' must be applied to the countable plural nouns. For instance, in Sentence no. 1 and no. 2, the correct nouns should be 'members' and 'taxes instead of 'member' and 'tax'. Both words 'our family' and 'various' placed before the nouns give the clue to the students that the noun should be in plural form. As for the Sentence no. 3, it is clear that the students did not know that both words 'homework' and information' are considered as uncountable nouns. Thus, it is not necessary to add the suffix ' $\mathrm{s}$ ' to the nouns. 
1) Internet help us to connect with our family member (members) or beloved ones who are at the foreign country.

2) It makes life easily, for example shopping online, pay various tax (taxes) online and so on.

3) Most of them who using the Internet probably want to finish their homeworks, (homework) assignments, finding new informations (information) and so on.

\subsection{Preposition}

Preposition is also considered as one of the common grammatical errors committed by the students, indicating their poor knowledge of prepositions. From the students' written reports, the prepositions were used interchangeably. For the students, prepositions do not affect the meanings of their sentences. Thus, they are not so particular on the use of prepositions in their sentences. Carelessness appears to be one of the primary causes of such errors. For example:

1) The percent of internet penetration clearly increase $\underline{\boldsymbol{b}}$ (for) the North of America.

2) If not, they will die from (of) hunger.

3) They have to search some information that is related with (to) their findings.

4) $\underline{\boldsymbol{B} \boldsymbol{y}}$ (Through) internet, this country can introduce their products by promoting it through the entire social website and expanding their business using it.

5) We can do other jobs before we want to spend time in (on) the internet.

6) Parents that have kids who is using internet to learn in (at) an early age is a good method.

7) As we can see on (in) the graph, Africa has the lowest percent among the others.

\subsection{Adjectives}

Wrong application of adjective can be seen when students did not apply the conventional rules for forming correct comparative form of one or two-syllable adjective in the sentences. If the two-syllable adjectives such as 'easy' and 'busy' which end in ' $y$ ', then the ' $y$ ' has to be changed to 'i' before adding the ending. So, the correct forms of adjectives in Sentence 1 and 2 are 'easier' and 'busier'. On the other hand, if the one-syllable adjective ends with a single consonant preceded by a vowel, then one should double the consonant and add -er. This rule applies for Sentence no. 3 whereby the correct form should be 'better' instead of 'more better'.

1) Some people nowadays prefer using internet which is more easy (more easier) than finding any informations from newspapers, magazines and books.

2) This is why North America become busy and busier (busier) each day.

3) Therefore, their technology is far more better (better) than the Africas'

\section{Other Related Findings}

\subsection{Spelling Errors}

In this section, sample of students' spelling errors are displayed and the errors identified in each sentence is shown accordingly in the words. The examples of spelling errors only show the errors in the area specified. Other errors in the sentences are not taken into consideration. About twenty-eight students had spelling problems in writing, like confusion with word of similar spelling as shown below:

'technologys'(technologies), 'devolove'(develop), 'goverment'(government). 'happend'(happened), 'knowladge' (knowledge), 'aducation' (education), 'cerreer' (career), 'lifes' (lives), 'tecnologi' (technology). 'morden' (modern), 'higest' (highest), 'importang' (important), 'obsesion' (obsession), 'middel' (middle), 'contries' (countries), 'buisness' (business), 'by' (buy)

The results revealed that the students confused words with similar spelling but different meanings. They also showed confusion in spelling while they write. It can be inferred that the cohort of students had challenges faced in their writing, which could be due to the influence or interference of their mother tongue.

\subsection{Omission}

Another error the students made in their writing was omission. Omission is any deletion of certain necessary items in sentences. The errors are the omission of articles, verbs, and prepositions. The students' inability to include certain words in their essays revealed their weaknesses in writing as shown in the example below:

\footnotetext{
"Africa is the country that ( ) not have the ..."
} 
As explained in misformation Example 1, generalization requires the noun to be either singular or plural. The predicate in the sentence is "is" which is for singular nouns. Therefore, was supposed to be the article "a" before the proper noun "Africa". The best correction is:

\section{"Africa is (a) country that ( ) not have the ..."}

As explained in misformation Example 2, generalization requires the noun to be either singular or plural. The predicate is 'is' which is for singular nouns. Therefore, there is supposed to be the verb 'does' after the noun phrase "country that'. The best correction is:

"Africa is (a) country that (does) not have the ..."

The statement above generalizes any "Africa", so the rule of generalization (Azar, 1999) must be applied. The words don't and doesn't (contractions of do not and does not) must, like all other verbs, agree with their subjects. Mistakes are often made with these forms.

\section{Conclusion}

As presented in the data, there are nine types of grammatical errors made by the ESL students, including errors in Subject-Verb Agreement, Verb Tense, Noun, Preposition, Adjective, Article, Pronoun, Adverbs and Conjunctions. The analysis of the students' grammatical errors revealed that these students have poor command of the English language. Errors are expected in the process of learning and it is very important to identify the cause behind their occurrence. In most cases, errors occurred from what Richards (1973) proposed as overgeneralisation and ignorance of rule restrictions. This study can illuminate certain issues pertaining to how school teachers can help their students to produce better essay writing by understanding students' weaknesses in writing. Teachers can modify their teaching styles based on the students' needs or writing errors. The students made grammatical errors in the writing as they had inadequate grammatical knowledge. The results of this study suggest some ways for ESL teachers to enhance students' writing, specifically by providing some feedback after marking their essays and also making the students rewrite the essays after corrections. Teachers can integrate grammar instruction with writing instruction; they should use the grammar terms that make sense to the students (Chin, 2000). By incorporating grammar terms naturally into the processes of editing, revising, and proofreading, teachers can help students understand and apply grammar purposefully to their own writing. Strategies such as writing conferences, partnership writing, grammar mini lessons, and peer response groups are all valuable methods for integrating grammar into writing instruction (Chin, 2000). Although this study was undertaken on a very small scale, the results of the study are quite significant. They show the possibility of teachers employing various strategies to assist students in applying grammatical concepts to achieve their writing purpose.

\section{References}

Azar, B. S. (1999). Understanding and using English grammar. New York: Pearson Education.

Braddock, R., Lloyd-Jones, R., \& Schoer, L. (1963). Research in written composition. Urbana, IL: National Council of Teachers of English.

Brown, H. D. (1980). Principles of language learning and teaching. New Jersey: Prentice-Hall Inc.

Bruner, J. S. (1975). The ontogenesis of speech acts. Journal of Child Language, 2, 1-40. https://doi.org/10.1017/S0305000900000866

Calkins, L. M. (1980). When children want to punctuate. Language Arts, 57, 567-573.

Carter, R. (1997). Investigating English discourse: Language, literacy and literature. London: Routledge.

Chin, B. A. (2000). The role of grammar in improving students' writing. Sadlier: Oxford.

Corder, S. P. (1967). The significance of learners' errors. International Review of Applied Linguistics, 5(4), 161-169.

Corder, S. P. (1978). Error analysis interlanguage and second language acquisition. Language Teaching \& Linguistics: Surveys, 6(4), 60-78.

Corpuz, V. A. F. (2011) Error correction in second language writing: Teachers' beliefs, practices, and students' preferences. Master of Education Thesis, Queensland University of Technology.

Crowley, B. P., \& Delfico, J. F. (1996). Content analysis: A methodology for structuring and analyzing written material. United States General Accounting Office (GAO), Program Evaluation and Methodology Division. Retrieved from http://www.gao.gov/assets/80/76281.pdf

Crystal, D. (1999). The penguin dictionary of language (2nd ed.). London: Penguin Books. 
Darus, S, \& Subramaniam, K. (2009). Error analysis of the written English essays of secondary school students in Malaysia: A case study. European Journal of Social Sciences, 8(3), 483-495.

DiStefano, P. \& Killion, J. (1984). Assessing writing skills through a process approach. English Education, 16(4), 203-207.

Foppoli, J. (2011). Is grammar really important for a second language student? Retrieved on January 10, 2015 from http://www.eslbase.com/articles/grammar.

Ganapathy, M. \& Kaur, S. (2014). ESL students' perceptions of the use of higher order thinking skills in English language writing. Advances in Language and Literary Studies, 5(5), 80-87.

Ghabool, N., Edwina, M., \& Kashef, H. S. (2012). Investigating Malaysian ESL students' writing problems on conventions, punctuation, and language use at secondary level. Journal of Studies in Education, 2(3), 131-143. https://doi.org/10.5296/jse.v2i3.1892

Harris, R. J. (1962). An experimental inquiry into the functions and value of formal grammar in the teaching of written English to children aged twelve to fourteen. Ph.D. dissertation. University of London.

Hillocks, G., Jr. (1986). Research on written composition: New directions for teaching. Urbana, IL: ERIC Clearinghouse on Reading and Communication Skills and the National Conference on Research in English.

James, C. (2001). Errors in language learning and use: Exploring error analysis. Beijing: Foreign Language Teaching and Research Press.

Kaufman, A. S., \& Kaufman, N. L. (2004). Kaufman assessment battery for children (2nd ed.) (K-ABC-II).Circle Pines, MN: American Guidance Service.

Khairiah, A. (1970). Factors influencing the learning of English Language in selected Malay medium schools in Malaysia - A research proposal. Jurnal Pendidikan, 1(1).

Krashen, S. D. (1985). The input hypothesis: Issues and implications. New York: Longman.

Mohtar, T. M. T., Kepol, N., Ahmad, A. Z. L, Singh, S. C. K, Yan, N., \& Mat, M. (2017). Validation of the scaffolding model and modules for teaching ESL writing skills in national schools in Malaysia. Unpublished ERGS Research Report, Universiti Pendidikan Sultan Idris, Tanjong Malim.

Musa, C. N., Lie, Y. K., \& Azman, H. (2012). Exploring English language learning and teaching in Malaysia, Journal of Language Studies, 12(1), 35-51.

Myles, (2002). Second language writing and research: The writing process and error analysis in student texts. Retrieved on 2.3.2017 from http://tesl-ej-org/ej/22/al.html

Naeini, J. (2008). Error correction: An indication of consciousness-raising. Novitas ROYAL (Research on Youth and Language), 2(2), 120-137.

Narinasamy, I., Mukundan, J., \& Nimehchisalem, V. (2013). The use of progressives among Malaysian ESL students. English Language Teaching, 6(11), 39-48. https://doi.org/10.5539/elt.v6n11p39

Noraisah Muhari \& Wan Fara Adlina Wan Mansor. (2008). An analysis of ESL students' multimedia project work: A case of language transfer. (Unpublished project paper). Universiti Teknologi Malaysia, Malaysia.

Nor Hashimah Jalaluddin, Norsimah, M. A., \& Kesumawati, A. B. (2008). The mastery of English language among lower secondary school students in Malaysia: A linguistic analysis. European Journal of Social Sciences, 7(2), 106-119.

Nunan, D. (1999). Second Language Teaching and Learning. USA: Heinle \& Heinle Publishers. Richards, J. C. (ed). (1973). Error analysis. London: Longman.

Palpanadan, S., Fauziah, I., \& Abdul, R. S. (2015). Role of model essays in developing students writing skills in Malaysian schools: A review of literature. Mediterranean Journal of Social Sciences, 6(2), 56-61.

Pandian, A. (2006). Whatworks in the classroom? Promoting literacy practices in English. $3 L$ : Language, Linguistics, Literature, 11, 1-25.

Ramaiah, M. (1997). Reciprocal teaching in enhancing the reading ability of ESL students at the tertiary level. Unpublished PhD Thesis. University of Malaya, Kuala Lumpur, Malaysia.

Richards, J. C. (Ed.). (1973). Error analysis. London: Longman. 
Rogers, C. R. (1967). The interpersonal relationship in the facilitation of learning. In T. Leper (Ed). The person in the process. Washington, D. C.: National Education Association, Association for Supervision and Curriculum Development, pp. 1-18.

Ruziah, Md. Z. (2006). Enhancing the correct use of prepositions through error identification drill exercises among the KPLI (M) students. JURNAL IPBA, 3(3), 10-15.

Saadiyah, D., \& Subramaniam, K. (2009). Error analysis of the written English essays of secondary school students in Malaysia: A case study. European Journal of Social Sciences, 8(3), 483-495.

School Certificate Attainment Report (2005). Ministry of Education, Malaysia (Laporan Prestasi SPM, 2004 Pengarah Peperiksaan, Kementerian Pendidikan Malaysia).

Shaughnessy, M. P. (1977). Errors and expectations: A guide for the teacher of basic writing. New York: Oxford University Press.

The Star Online. (2014). Kulasegaran: SPM results 2014: Overall performance takes a dip. Retrieved from http://www.thestar.com.my/news/nation/2015/03/03/spm-results-down/

Vygotsky, L. S. (1978). Mind society: The development of higher psychological processes. Cambridge, MA: Harvard University Press.

Wee, R. (2009). Sources of errors: An interplay of interlingual influence and intralingual factors. European Journal of Social Sciences, 11(2), 349-39.

Wee, R., Sim, J., \& Jusoff, K. (2009). Enhancing the quality of EAP writing through overt teaching. English Language Teaching, 2(3), 58-68. https://doi.org/10.5539/elt.v2n3p58

Wee, R., Sim, J., \& Jusoff, K. (2010). Verb-form errors in EAP writing. Educational Research and Review, 5(1) 16-20.

Zerin, S. (2007). Teaching writing to young learners. BRAC University.

Zheng, C., \& Park, Tae-Ja. (2013). An analysis of errors in English writing made by Chinese and Korean university students. Theory and Practise in Language Studies, 3(2), 1342-1360. https://doi.org/10.4304/tpls.3.8.1342-1351

\section{Copyrights}

Copyright for this article is retained by the author(s), with first publication rights granted to the journal.

This is an open-access article distributed under the terms and conditions of the Creative Commons Attribution license (http://creativecommons.org/licenses/by/4.0/). 